\section{EMBRYRIDDLE}

Aeronautical University

SCHOLARLY COMMONS
Journal of Aviation/Aerospace Education \& Research

Volume 14

Number 1 JAAER Fall 2004

Article 8

Fall 2004

\title{
Publishing Aviation Research: A Literature Review of Scholarly Journals
}

Robert W. Kaps

Ed Phillips

Follow this and additional works at: https://commons.erau.edu/jaaer

\section{Scholarly Commons Citation}

Kaps, R. W., \& Phillips, E. (2004). Publishing Aviation Research: A Literature Review of Scholarly Journals. Journal of Aviation/Aerospace Education \& Research, 14(1). https://doi.org/10.15394/jaaer.2004.1539

This Article is brought to you for free and open access by the Journals at Scholarly Commons. It has been accepted for inclusion in Journal of Aviation/Aerospace Education \& Research by an authorized administrator of Scholarly Commons. For more information, please contact commons@erau.edu. 


\title{
PUBLISHING AVIATION RESEARCH: A LITERATURE REVIEW OF SCHOLARLY JOURNALS
}

\author{
Robert W. Kaps and Ed Phillips
}

\begin{abstract}
The importance of the aviation industry's socio-economic impact, domestically and globally, cannot be denied. In light of this and, as aviation continues to evolve as an academic field of study, post-secondary institutions with aviation specific curriculum have grown, in number and prominence. As a direct consequence of academic growth, the necessity to publish follows as a concomitant requirement. Through the diligence of those researchers actively conducting aviation related research a common theoretical and conceptual base for aviation specific research has been established. The void that once existed for aviation research has been filled, predominantly by three aviation specific journals and a number of other journals of prominence that accept aviation research for publication.

In a 1995 article entitled Publishing Aviation Research: An Interdisciplinary Review of Scholarly Journals, Truitt and Kaps, using a specialized computer research criterion, and key informant interviews identified a list of 21 aviation specific and related publication outlets available for publishing. This research procedure and methodology received additional validity when the University Aviation Association codified the findings into a UAA publication entitled, Directory of Scholarly Journals Which Publish Non-Engineering Aviation Research. Replication of that study and by expanding the field of search mechanisms, the authors set out to determine the present field for aviation publications, both scholarly and non-scholarly. Twenty-nine academically peer reviewed journals are included in this update. The results validate the previous study, and identify and define, through tabular exhibits, contact points, addresses and email and/or web site locations of previously sited locations and those emerging subsequent to the UAA listing. In addition, this current effort adds new perspectives on the reasons for publishing and who might be encouraged to publish in what type of journal.
\end{abstract}

\section{PURPOSE OF THE STUDY}

This study promotes the importance of published research to the field of aviation in the academic environment. Providing a five-part argument supports the publishing process. This discussion addresses why publishing is important, through identifying three distinct groups of individuals who may desire and or be encouraged to publish, while providing the academic community with three distinct lists of publications where manuscripts may be submitted for consideration. The Tables included in this article serve as a ready reference for answering the question "Where can I publish my research?" This article continues an earlier effort (Truitt \& Kaps, 1995) to identify the number and type of academic publications serving the field of aviation research.

\section{AUDIENCE}

This article is addressed to three distinct groups within the community of aviation education. The first group is tenure track professors who balance the challenge of teaching, service and research as a basic job requirement. It is this group, who has, both by necessity and concern, been the driving force in aviation research at the university level. With inordinate emphasis placed on the tenure/tenure track professionals, other potential contributing groups may have been overlooked, or, have, by necessity taken a research backseat. Thus, the following two groups have perhaps been traditionally forgotten in the discussion about publishing research. This oversight may constitute a systemic failure and loss of potential insight.

The second group consists of administrators (such as advisors) and non-tenure track instructors. Both have academic and aviation knowledge and skills, and some have the desire to add to the body of aviation research.

The third group consists of the students. Oftentimes student work completed for class projects and papers is exemplary and deserves to be shared with the aviation community.

Overall, the perspective of this article is the academic community where English is the common language. 
However, the material will hopefully be of value to worldwide members of the aviation community who wish to share their research efforts with others.

\section{BACKGROUND}

The field of aviation education has undergone dramatic changes in its relatively short history. Worldwide interest in aviation has grown exponentially since World War II, particularly since the introduction of jet aircraft made air transportation the mode of choice for domestic and international transportation. Considerable interest in aviation has developed in the academic community. This reflects the importance of aviation to a nation's economy and security. Aviation in the United States faces severe operational challenges with new security measures, an aging air traffic control system, a history of poor financial performance by major carriers, tense ongoing labor negotiations, forced layoffs of thousands of employees, etc. As society faces these challenges, the need for creative, realistic and meaningful research for solutions is obvious.

Fortunately we enter this period with a record of success among university aviation programs. Aviation education has emerged as a major field of study. Aviation programs do not enjoy - and perhaps never will - the status of the hard sciences. Aviation does not appear to have the recognition and support for research that is granted to programs in established disciplines like physics, mathematics or in the social sciences such as economics, political science, or mass communication. This is due in part to the realization that scholars in such traditional academic disciplines have not previously appreciated aviation education for a variety of reasons; its historical mission of vocational education, its applied, rather than theoretical orientation, and, heretofore, the failure of aviation faculty to publish research. Increasing the amount of high quality published research may never put aviation on scientific par with biochemistry, but the gap can and will be narrowed. At least three factors coalesced and helped create this gap. First, is that by the very nature of the program, aviation educators have historically concentrated on providing students with applied knowledge -training, and skills in technical areas such as flight and maintenance. Secondly, many members of the aviation faculty and staff have business or military expertise in fields for which many academicians have no frame of reference. This results in a widely diverse perspective about some components of the education process! Surprisingly the third factor is geography. Many aviation staff members have little opportunity to interact with their counterparts in the more mainstream academic research areas because aviation programs are often located away from the main campus at the airport or in a cockpit.

\section{WHY RESEARCH IS IMPORTANT}

Aviation educators are constantly trying to understand the educational process and must make professional aviation oriented decisions and teaching assessments that have both immediate and long range effects on students, teachers and industry professionals. Information concerning this process comes from many sources, but research systematically describes a measurement of reality, and is a better source of knowledge than one's own experiences, beliefs or intuitions. Thus, the research component of the educator's repertoire can be interesting and relative to others in the field, and others in related fields of concern.

Aviation research is required for at least six distinct reasons. The first reason is to meet critical challenges facing the industry. General aviation, large and small commercial carriers, components of the U.S. Federal government such as the Transportation Safety Administration (TSA) and Federal Aviation Administration (FAA), all face severe challenges. Secondly, continued research is required by academicians to insure they provide students with the most current and effective knowledge and procedures available. This only occurs with constant effort to keep abreast of fast and ever changing technology and operating philosophies within the field. An instructor well grounded in his or her field is more effective and more comfortable in the teaching environment, than one who is only a textbook chapter ahead of the students. Third, is to maintain and advance the relative position of aviation within the academic community requires cementing and improving a reputation for meaningful research. Grants, manpower, facilities and other resources tend to flow to those areas that are viewed as contributing the most. As McGuire and his associates point out, "...it is institutional reputation that top administrators at research universities strive to enhance by increasing and/or shifting research resources" (McGuire, Richman, Daly, and Jorjani, 1988). Fourth, some faculty members must publish as a condition of employment. This involves the typical aspects of obtaining tenure and qualifying for advancement to the next level of the academic pyramid. The fifth reason is comparative. Essentially scores of management oriented academic journals publish articles under that broad heading. The academic aviation community must demonstrate that it is capable of the same scholarly rigor as management and other disciplines. And lastly, parttime faculty, administrative staff, and students should be encouraged to publish research. Many of these individuals have exciting ideas and or a desire to be published. Their ideas may help both solve some of the aviation community challenges and simultaneously provide personal reward for meaningful research and writing. Encouraging members of 
this part of our community to publish can be used as a positive motivation tool.

Unfortunately the aforementioned six reasons of why aviation research is important are not necessarily supported by the institutional values necessary to develop and sustain an active research agenda. Three values are especially important: reasonable teaching loads, release time, and research awards (Kramer and Perry, 1989). Clearly, faculty must have the time to conduct research. Research universities generally recognize this need and set teaching loads for faculty members in most colleges and departments accordingly. However, this is typically not, true for most aviation educators, who regularly teach the equivalent of seven or more courses annually. Colleges and universities that demand and expect research productivity from their aviation faculty must adjust teaching loads to realistic levels. A related institutional value is release time from teaching for research. In addition to reducing teaching loads, universities must promote research by allowing aviation faculty to "buy out" teaching time with research grants. The third important institutional value necessary to promote research productivity is to recognize and reward research performance. Teaching and public service are activities that often carry immediate rewards. In contrast, research involves long lead times and large investments of time and effort. Researchers must be given incentives such as awards, honors, and recognition for their efforts. In addition, university administration should encourage faculty to consult with outside organizations. The foregoing normative statements notwithstanding, these institutional incentives for research are not likely to be forthcoming in the immediate future given the scarcity of resources that exist at most college and university aviation programs. Thus, it is incumbent on individual members of the aviation faculty to publish and demonstrate that aviation programs are worthy of institutional "respect" and support. Publication of research is vital if aviation educators hope to gain esteem from their peers and institutional support for additional research.

\section{OPPORTUNITIES}

In the past, the opportunities to publish aviation research were limited. Although aviation education has made rapid progress during the past two decades, it continues to be a fragmented and balkanized field of study. Aviation programs are housed in a variety of colleges and departments. Traditionally, aviation educators have published their research in the disciplinary journals in which their programs are aligned. For instance, professors that teach aviation flight and/or maintenance, publish their research in a variety of technical and vocational education journals. Likewise, professors that are affiliated with management departments generally publish articles in business joumals. This situation is not conducive in bringing the field of aviation to its full potential, nor has it permitted the systematic accumulation of a compendium of immediately available information. However, growing recognition of the vital role that aviation plays in modern society has caused aviation education and research to receive more attention in the academic community.

New journals are being established every year; there are more opportunities to publish aviation research today than in the past. This work identifies approximately a $38 \%$ growth (from 21 to 29) in available academically peer reviewed publications in the past eight years. In this metamorphosis, the final state toward which journal literature is evolving in the age of network hyper-media is inevitable, as more and more on-line journals are being developed. According to Hamad (1998) the entire corpus of research will be fully and freely accessible and navigable from the desk of any thinker in the world.

\section{SCHOLARLY RESEARCH}

One caveat concerning scholarly research vis-à-vis generalized research is in order, before proceeding further. While this article concentrates on the entire genre' of publication venues accepting aviation articles, it must be emphasized that true scholarly research has some specificity of its own.

Because there are different requirements for the diverse type of publications, a comparison of the scholarly publication requirements versus more 'popular' material is in order.

Scholarly research, writing to be incorporated into scholarly journals, has as its very basic characteristic, the intent of being 'new knowledge,' or, the addition to the body of knowledge in the specific field of study. Popular articles, trade news and special interest articles, although new to some readers, are generally not the product of scholarly research and are, therefore, intended to inform and/or entertain the reader.

Unlike most general publication articles, scholarly articles are peer-reviewed before publication and always include extensive notes, a bibliography or both. In addition the author's professional and/or academic credentials are listed, thus establishing and providing the authority to endow validity. This is in complete contrast to popular publications, which require no special knowledge of the field of discussion. Scholarly work, on the other hand, requires prior knowledge of the subject matter, and, generally the articles contain formal subject specific terminology without explanation. 
A scholarly research article should follow some very basic and elementary guidelines, although the content is anything but elementary. Thus, it should contain footnotes, a bibliography and the author's credentials. The main text should contain a description of how the author(s) designed and conducted the study, followed by a complete report of the findings and, if necessary, a statistical analysis of the results. Recommendations for further study are often included.

Those who actually conduct the original study or experiment, and should detail how it was designed, conducted and analyzed should always write a research article.

Despite there being no clearly defined or specific definition of what constitutes a scholarly article, most libraries in the university system outline some specifics for writers. For example, the John M. Pfau Library at the California State University at San Bernadino cites ten criterions, identified either by commission or omission, as requirements of scholarly journals. Likewise, the Library at the University of Indiana highlights nine requirements. Both are so closely coincident that the ten of the Pfau Library are identified. Scholarly articles should:

1. Add to the body of knowledge in a specific field of study.

2. Be peer reviewed.

3. Include extensive notes, or a bibliography, or both.

4. Contain the authors professional or academic credentials and indicate a methodology for contacting the author

5. Indicate and have prior knowledge of the subject matter for full comprehension of the article.

6. Include language that is formal where jargon or specialized terms may be used without explanation.

7. Include graphics only when necessary to support text (such as charts \&/or tables).

8. Have a layout that is simple and uniform; all articles will follow the same basic format.

9. Have little or no color, and

10. Contain little or no advertising

A level down from pure analytical research is metaanalysis. This is a research undertaking that results in a determination of previous reported research. It is the result of several existing studies and analyses, looking for previously unnoticed patterns, trends or possible overlooked information. Often times, meta-analysis will uncover new data from previous research.
One other category of scholarly research is the literature review. This work is a summation of previously reported literature on a particular subject. While useful to those who do absolute research, literature reviews do not fall into the genre' of 'hard' empirical research

\section{RESEARCH METHODS}

The goal of this effort is to provide a comprehensive list of publishing outlets for aviation research. A Google search of aviation publications results in over 500,000 hits. One search of a highly respected list of publications identified four academic peer reviewed publications. Neither extreme is particularly helpful. A systematic computer search of several of the major library indices was conducted using advice from professional librarians. When the available information was unclear or missing, an effort was made to contact editors (primarily by email) for clarification. This effort resulted in identifying both academic and nonacademic peer reviewed publications.

Urlich's Periodicals Directory was first published in 1932. Now in electronic form it identifies refereed publications as those "refereed or peer-reviewed by an editorial board" (ulrichsweb.com, 2/25/03). This demonstrates that not all refereed publications are refereed by academic peers of those who wish to publish for purpose of tenure or promotion. It also demonstrates the difficulty of simply using a single search of even a highly respected electronic index to find an optimum list of academic peer reviewed publications.

The search conducted results in publications grouped into four categories.

1. Aviation specific academically peer reviewed publications, Table 1 . This category includes a variety of areas dedicated solely to aviation. Included are journals primarily for aviation education, some to law, some are more general. This group of publications might be considered the first choice of those who wish to publish research that meets criteria for tenure and promotion. The earlier list published by Truitt \& Kaps (1995) included eight journals specific to aviation. Table 1 includes 12 such journals.

2. Non-aviation specific academically peer reviewed publications, Table 2. These publications fall within a transportation category. Subject matter includes aviation. However, the overall focus of the journals includes other modes of transportation and large span issues. Aviation related research is welcomed and appreciated, but the number of aviation articles may be small in relation to total articles published. This category is probably an 
equally good choice for those who wish to have their published research count toward tenure and promotion but who can't find a niche in one of the aviation specific journals.

3. Aviation related journals refereed by an editorial board, but not reviewed by members of the aviation academic community, Table 3 . This category was not included in the earlier Truitt \& Kaps (1995) work. Material submitted for consideration to these publications would probably receive a quicker - perhaps much quicker decision than researchers will receive from the peer review process in the first two categories. The hurdle for acceptance may not be as high as it is for the first two categories. This list of publications is perhaps a good choice for those who primarily want to have their research efforts shared publicly to offer answers to industry problems and to receive the personal satisfaction of being published. The value of the publication, and, or an author's research is not necessarily determined by the process by which the article is selected for publishing. Such articles may not meet the stringent requirements for tenure and promotion. However, a student or department administrator who publishes in one of these vehicles receives both personal satisfaction, and brings some credit to his or her department.

Table 3 includes seven journals. The seven are aviation or transportation specific and are included as examples. This is not intended to be a complete list, but a representative listing. Researching, and, or writing an article published in Business Week, Fortune, the Harvard Business Review would be a plus for anyone's vitae or resume. The journals for many professional organizations such as "The Proceedings" of the $U$. S. Naval Institute are highly reputable and being published in such a journal is a creditable achievement. The Journal of Marketing, the Journal of Management, Public Administration Review, or a host of other flagship journals in major disciplines are also attractive targets for aviation research. Table 3 therefore should be viewed not as a limiting list, but only an entry into a wide field of opportunity.

4. The fourth category of publications makes no attempt to claim any referred process when selecting articles for publication. It is possible to argue that any published article has been reviewed and approved by at least some process. That is valid but the interest in many if not most of the editors of publications in this fourth category falls under the headings of possible sales impact, pure reader interest, etc.

There is no intent to suggest that publications in this category be somehow "less than" those in the first three. Ultralight Flying is an example. It is assumed that the editorial staff of this monthly magazine works professionally and with great creativity to produce a quality product that appeals to its readers. However, an aviation student publishing a story in Ultralight Flying seems somehow less applicable to the academic process than if the same student researched an article on baggage screening that was published in Aviation Security International (which is listed in Table 3).

This fourth category is by far the largest. Various lists, several of which are longer than this article, may provide information when researching a particular subject as well as excellent general knowledge and simple pleasure. But, they are of little value for easily identifying refereed publications. A few examples follow:

- www. aero.com - 31 pages of aviation publications listed by subject areas such as apparel and rotorcraft.

- www.airaffair.com - 13 pages of aviation publications and associations' publications.

- homepage.ntlworld.com - 11 pages of aviation publications and links.

Category 4 is added not to provide a source for academic research but to recognize that this large body of aviation published material exists. The publications would not exist without individuals interested in aviation sharing their experiences, ideas, and comments. This sharing is a good thing! It is not; however, the same as publishing something that may help an individual's or a department's academic standing.

\section{CONCLUSION}

Clearly, there are more opportunities for aviation educators and professionals to get their papers in print than there was eight years ago. The listings provided here offer a comprehensive compendium of aviation specific and nonaviation specific academically peer reviewed journals and some attractive non-academic journals that publish aviation research. The scope and breadth of the publications 
identified herein has established a common theoretical and conceptual base for aviation research. Aviation has matured as a science that has emerged as a recognized field of study. This study does not imply that the work is over; continuing research and publishing efforts will be critical for maintaining this research foundation. And, this article suggests that thought and effort be given to encouraging and helping those both in and not in tenure track positions to seek ways to publish ideas necessary for the aviation community to address its many challenges. +

Robert W. Kaps earned a Bacheló of Science degree in Business Administration from Washington University, Master of Arts in Legal Studies and a Master of Arts of Human Resource Development from Webster University, and a Ph.D. in Workforce Development from Southern Illinois University, Carbondale. He is an Associate Professor of Aviation Management at Southern Illinois University where he teaches in the Aviation Management baccalaureate and the Master of Public Administration programs. Prior to joining the Academy, Dr. Kaps spent over twenty-two years in the airline industry in various executive positions with both Major and National air carriers. He has published numerous articles in the aviation venue and has authored two books in the aviation field, Air Transport Labor Relations and Fiscal Aspects of Aviation Management.

Ed Phillips spent 29 years in a variety of managerial positions at United Airlines that included offices in seven different airports and corporate headquarters. He also has a combined 22 years active and reserve Navy experience including commanding five different organizations. In 1995 he retired and went to graduate school earning a Masters and Ph.D. in Speech Communication while teaching basic speech classes and assisting coaching a national championship debate team. For the past three years he's been a visiting lecturer teaching aviation management classes at Southern Illinois University Carbondale. 


\section{REFERENCES}

Barker, B. M., NewMyer, D.A., Truitt, L.J., Kaps, R.W., \& Fuller, M. L. (1995, September). Directory of Scholarly Journals Publishing Non-Engineering Aviation Research. University Aviation Association, Auburn, AL.

Hanard, Steven (Sept. 10, 1998). Online journals \& financial firewalls. Nature, 127-128.

Kramer, K L., \& Perry, J. L. (1989). Institutional requirements for academic research in public administration. Public Administration Review, 49, 9.

McGuire, J. W., Richman, M. L., Daly, R. F., \& Jorjani, S. (1988). The efficient production of 'reputation' by prestige research universities in the United States. Journal of Higher Education, 59, 368.

Truitt, L. \& Kaps, R. (1995). Publishing aviation research: An interdisciplinary review of scholarly journals. Journal of Studies in Technical Careers, XV(4). Carbondale, IL

Ulrich: periodical directory (2/25/03). http://www.ulrichsweb.com

Scholarly versus popular periodicals, http://www.indiana.edu

Characteristics of popular magazines and scholarly journals http://www.lib.csusb.edu -magedanz/scholarly\&scholarlyjournals.htm 
Table 1. Aviation specific academically peer reviewed publications.

\begin{tabular}{|c|c|c|}
\hline $\begin{array}{c}\text { Title } \\
\text { Years Published/ } \\
\text { Publishing Schedule }\end{array}$ & Focus & Web Link \\
\hline $\begin{array}{l}\text { Air \& Space Law } \\
\text { 28/Bi-monthly }\end{array}$ & $\begin{array}{l}\text { Published by Kluwer Law International, Netherlands since } 1975 \text {. The publication is } \\
\text { available in a paper or online version }\end{array}$ & $\frac{\text { www.iasl.mcgill.ca/ }}{\text { annalsof.htm }}$ \\
\hline $\begin{array}{l}\text { The Air and Space Lawyer } \\
\text { S/Quarterly }\end{array}$ & $\begin{array}{l}\text { Air and Space Law is one of several Fonums of The American Bar Association. This Forum } \\
\text { has nearly 2,000 members from areas such as airlines, aircraft manufacturers, general } \\
\text { aviation, and the DOT and FAA. Positioned as a "newsletter" of the Forum articles are } \\
\text { considered for inclusion. There is a selection process but information regarding juried } \\
\text { review by other academicians is unavailable. First published in } 1998 \text {. }\end{array}$ & $\begin{array}{l}\text { www.abanet.org/abapubs/ } \\
\text { periodicals/airspace.html }\end{array}$ \\
\hline $\begin{array}{l}\text { Air Traffic Control } \\
\text { Quarterly } \\
\text { 10/Quarterly } \\
\end{array}$ & $\begin{array}{l}\text { The emphasis is air traffic control and emphasis on new developments and technology. } \\
\text { It is a peer-reviewed journal (S. Matthews, personal communication, February } 24,2003 \text { ). }\end{array}$ & www.atca.org/ \\
\hline $\begin{array}{l}\text { Annals of Air and Space } \\
\text { Law } \\
\qquad 28 / \text { Annually }\end{array}$ & $\begin{array}{l}\text { Published by McGill University in Montreal, Canada beginning in 1975. The renowned } \\
\text { Institute of Air and Space Law sponsors this publication. Articles on legal issues in the } \\
\text { international air transport sector are the primary areas of concentration. Submissions are } \\
\text { accepted in French or English. }\end{array}$ & $\begin{array}{l}\text { www.iasl.mcgill.cal } \\
\text { publications/ } \\
\text { annals/index.htm }\end{array}$ \\
\hline $\begin{array}{l}\text { Collegiate Aviation Review } \\
\text { (CAR) } \\
\text { 20/Annually }\end{array}$ & $\begin{array}{l}\text { This journal publishes papers and articles that are subsequently presented at the University } \\
\text { Aviation Association's annual fall conference. The CAR has published aviation research } \\
\text { that covers a range of subjects from a variety of perspectives, including human factors, } \\
\text { airline management, airports and airways, and aviation education. It has been in publication } \\
\text { since 1983. }\end{array}$ & $\begin{array}{l}\text { uaa.auburn.edu/ } \\
\text { publictn.htm }\end{array}$ \\
\hline
\end{tabular}




\begin{tabular}{|c|c|c|}
\hline $\begin{array}{c}\text { International Journal of } \\
\text { Aviation Psychology } \\
\text { 12/Quarterly }\end{array}$ & $\begin{array}{l}\text { Professor Richard Jensen of Ohio State University's Department of Aviation edits the } \\
\text { journal. The journal publishes research associated with the design, development and } \\
\text { management of safe, effective aviation systems from the standpoint of human operators. } \\
\text { This quarterly has been in existence since } 1991 \text { and is a potential outlet for those involved } \\
\text { in human factor research, human-machine interfaces, flight and air traffic simulators, and } \\
\text { cockpit resource management studies. This journal is truly interdisciplinary and draws upon } \\
\text { the resources of educators representing many disciplines including engineering, } \\
\text { psychology, education, physiology, medicine, sociology, and business (Jensen, 1991). }\end{array}$ & $\begin{array}{l}\text { www.erlbaum.com/ } \\
\text { Journals/journals/IJAP } \\
\text { /ijap.htm }\end{array}$ \\
\hline $\begin{array}{c}\text { Journal of Advanced } \\
\text { Transportation } \\
\text { 36/Tertiary }\end{array}$ & $\begin{array}{l}\text { Published by the Canadian Institute for Transportation, Inc. Articles address analysis, } \\
\text { design, economics, engineering, operations, planning and technology of all transportation } \\
\text { modes. }\end{array}$ & $\begin{array}{l}\text { www.advanced- } \\
\text { transport.com/ }\end{array}$ \\
\hline $\begin{array}{c}\text { Journal of Air and Law } \\
\text { Commerce (JALC) } \\
\text { 73/Quarterly }\end{array}$ & $\begin{array}{l}\text { Published by the Southern Methodist Law Review Association, at SMU, Dallas, the JALC } \\
\text { is the oidest, in publication since } 1930 \text { and one the most prestigious aviation journals. The } \\
\text { JALC focuses solely on aviation issues and has an extensive history as a forum for research } \\
\text { in aviation and space concerning legal and economic perspectives. Some of the classic } \\
\text { studies on the subject of airline regulation and administrative behavior, Suspected } \\
\text { Unapproved Parts, and Fractional Ownership of Business Aircraft have been published in } \\
\text { this journal. }\end{array}$ & www2.smu.edu/la/jalc \\
\hline $\begin{array}{l}\text { Journal of Air Transport } \\
\text { Management } \\
\text { 9/Bi-monthly }\end{array}$ & $\begin{array}{l}\text { This British publication position itself as a journal of research, policy and practice that } \\
\text { addresses the major issues facing air transport. Areas considered are policy, operations, } \\
\text { management, finance, etc. }\end{array}$ & $\begin{array}{l}\text { http://www.transportconn } \\
\text { ect.net/jairtraman/ }\end{array}$ \\
\hline $\begin{array}{c}\text { Journal of Air } \\
\text { Transportation World Wide } \\
\text { (JATWW) } \\
\text { 7/Semi-annual }\end{array}$ & $\begin{array}{l}\text { This journal will accept manuscripts on all topics that relate to air transportation, both } \\
\text { technical and non-technical. The JATWW panel of reviewers represents the } \\
\text { interdisciplinary nature of air transportation to ensure review by recognized experts. Broad } \\
\text { categories of appropriate topics include, but are not limited to: Aviation Administration, } \\
\text { Management, Economics, Education, Policy, Engineering, Technology and Science. It is } \\
\text { intended to serve aviation leaders as a key decision-making tool (Bowen, 1998). The } \\
\text { JATWW has been in publication since1996. }\end{array}$ & $\begin{array}{l}\text { www.unomaha.edu/ } \\
\text { jatww }\end{array}$ \\
\hline
\end{tabular}




\begin{tabular}{c} 
Journal of \\
Aviation/Aerospace \\
Education \& Research \\
(JAAER) \\
13/Tertiary \\
\\
\hline Journal of Avionics \\
Education (JAE).
\end{tabular}

Education (JAE).

9/Annually
This journal is a scholarly publication for educators and researchers as well as professionals in the aviation and aerospace industries. This journal is published by EmbryRiddle Aeronautical University in Daytona Beach, Florida and edited by William Kohlruss. The journal has been in existence since 1990. The types of article range from airline service quality and aviation education to the views of labor unions towards deregulation. The focus of JAAER is concerned with the interrelationship and influence of the aviation and aerospace community on the educational process and the influence of education on the aviation industry.

The JAE is a scholarly publication of the Association for Avionics Education published for educators, researchers, student, and industry, to explore issues, and concerns impacting aviation technical education and the aerospace and avionics industries. The purpose of the Journal is to provide a media through which educators, students, and aviation and aerospace professionals can share their opinions, concerns, and research findings on a full-range of topics central to avionics/aviation maintenance, technical, and educational issues

(http://www.avionicseducation.org/JAE_TOC.htm). The JAE has been in publication since 1994 (L. Russell, personal communication, April 13, 2001).

\begin{tabular}{|l|}
\hline $\begin{array}{l}\text { www.embryriddle.edu/res } \\
\text { earch/jaaer }\end{array}$ \\
\hline $\begin{array}{l}\text { www.avionicseducation } \\
\text { org/jae/_TOC.htm }\end{array}$ \\
\hline
\end{tabular}


Table 2. Non-aviation specific academically peer reviewed publications.

\begin{tabular}{|c|c|c|}
\hline $\begin{array}{l}\text { Title } \\
\text { Years Published/ } \\
\text { Publishing Schedule }\end{array}$ & Focus & Web Link \\
\hline $\begin{array}{l}\text { American Technical } \\
\text { Education Association } \\
\text { (ATEA) Journal } \\
\\
25 / \text { Quarterly }\end{array}$ & $\begin{array}{l}\text { Articles submitted to the ATEA should be lively, easy-to-read reports on interesting topics. } \\
\text { Action research, trends in technical education and industry, successful classroom and shop } \\
\text { practices and discussions of problems and solutions affecting the quality and scope of } \\
\text { technical programs. The first peer reviewed edition was published in } 1978 \text { (D. Leinen, } \\
\text { personal communication, April } 11,2001 \text { ). }\end{array}$ & www.ateaonline.org \\
\hline $\begin{array}{l}\text { Human Factors and } \\
\text { Aerospace Safety } \\
\text { 3/Quarterly }\end{array}$ & $\begin{array}{l}\text { This newer journal combines research papers with practioner papers about accident case } \\
\text { studies and safety and regulatory initiatives. Ashgate in the United Kingdom publishes the } \\
\text { journal. }\end{array}$ & $\begin{array}{l}\text { www.ashgate.com/ } \\
\text { subject_area/aviation/ } \\
\text { aviation_journals.htm }\end{array}$ \\
\hline $\begin{array}{l}\text { Human Factors: The Journal } \\
\text { of the Human Factors and } \\
\text { Ergonomics Society } \\
45 / \text { Quarterly }\end{array}$ & $\begin{array}{l}\text { In existence since 1957, this journal specializes in the human element of aviation. It } \\
\text { represents yet another potential outlet for aviation practitioners and educators to publish } \\
\text { their research. Aviation is one of many areas of human factors/ergonomics concerns; } \\
\text { therefore, the frequency of articles varies from year to year. Members of the publishing } \\
\text { organization, the Human Factors and Ergonomics Society, contribute many of the journal's } \\
\text { articles. }\end{array}$ & $\begin{array}{l}\text { hfes.org/Publications/ } \\
\text { HFJournal.html }\end{array}$ \\
\hline $\begin{array}{l}\text { Journal of Human } \\
\text { Performance in Extreme } \\
\text { Environments (JHPEE) } \\
\text { 7/Semi-annual }\end{array}$ & $\begin{array}{l}\text { The Society for Human Performance in Extreme Environments publishes the JHPEE. The } \\
\text { JHPEE is devoted to publishing research devoted to the study of human performance in } \\
\text { high-stress environments such as aviation, space flight, military, and other high-stress } \\
\text { environments. The goal of this publication is to consolidate the information from many } \\
\text { areas into one publication. Publishing all of this information in one place can help to } \\
\text { increase the understanding of the human-factor in high-stress environments. The JHPEE } \\
\text { has been in publication since } 1996 \text {. }\end{array}$ & $\begin{array}{l}\frac{\text { www.iasl.mcgill.cal }}{\text { annalsof.htm }} \\
\end{array}$ \\
\hline
\end{tabular}




\begin{tabular}{|c|c|c|}
\hline $\begin{array}{l}\text { Journal of Transportation } \\
\text { Geography (JTG) } \\
\text { 11/Quarterly }\end{array}$ & $\begin{array}{l}\text { The JTG, established in 1993, is an international publication released by Butterworth } \\
\text { Publishing in Oxford, England. This journal specializes in the discipline of geography as it } \\
\text { relates to spatial change in all modes of transport and telecommunications. The JTG } \\
\text { publishes papers from a geographic perspective covering a wide range of topics. These } \\
\text { topics include the impact of transport policies and infrastructure, the development of } \\
\text { transport networks, and environmental questions associated with transport and leisure. } \\
\text { From its inception the JTG has published a wide variety of aviation articles. One of the } \\
\text { initial editions featured an article describing US airline deregulation and its impact on the } \\
\text { distribution of inter-city airline traffic using origin-destination data from } 94 \text { cities. A } \\
\text { second paper published in the first edition examined deregulation's impact on the } \\
\text { distribution of inter-city airlines. }\end{array}$ & $\begin{array}{l}\text { www.elsevier.com/inca/p } \\
\text { ublications/store/ } \\
\text { 3/0/4/4/8/30448. } \\
\text { Pub.htt }\end{array}$ \\
\hline $\begin{array}{l}\text { Journal of Transportation } \\
\text { Management (JTM) } \\
\text { 15/Semi-annual }\end{array}$ & $\begin{array}{l}\text { The JTM is published by Delta Nu Alpha, a professional transportation fraternity. } \\
\text { This journal, in publication since 1988, publishes articles relating to all modes of } \\
\text { transportation. The editors are interested in papers that examine both the modal and inter- } \\
\text { modal aspects associated with movement of goods and people in both domestic and } \\
\text { international transportation. The editorial review board's major criteria for publication is } \\
\text { that articles submitted are of interest to both academicians and practitioners and that } \\
\text { "... articles are to have a real world orientation, those articles which are theoretical in } \\
\text { content, with no application for practitioners, are inappropriate for publication" (Journal of } \\
\text { Transportation Management, 1992). The journal's editors are interested in research that } \\
\text { addresses management and/or policy in the commercial segment of the air transport sector. } \\
\text { Examples are an article by former Civil Aeronautics Board regulator Matthew Scocozza } \\
\text { (1989) on the subject of airline merger policy, Barry Spraggins (1989) on the impact of } \\
\text { airline size on efficiency and profitability, and globalization of the airline industry } \\
\text { comparing domestic and European approaches to airspace congestion (Glisson, 1992). }\end{array}$ & $\begin{array}{l}\text { www.deltanualpha.org/pr } \\
\text { oducts.htm }\end{array}$ \\
\hline $\begin{array}{l}\text { Journal of Transportation } \\
\text { and Statistics (JTS). }\end{array}$ & $\begin{array}{l}\text { The JTS was founded in } 1998 \text { and is issued twice a year by the Bureau of Transportation } \\
\text { Statistics of the U.S. Department of Transportation. The purpose of the journal is to } \\
\text { increase the understanding of the role that the transportation industry has in our society and } \\
\text { the affects it has on our economy. The JTS accepts research on the use of information to } \\
\text { improve public and private decision making for the transportation industry. }\end{array}$ & $\begin{array}{l}\text { www.bts.gov/programs } \\
\text { /jts }\end{array}$ \\
\hline
\end{tabular}




\begin{tabular}{|c|c|c|}
\hline $\begin{array}{c}\text { Journal of Transportation } \\
\text { Research Forum (JTRF) } \\
\text { 34/Quarterly }\end{array}$ & $\begin{array}{l}\text { The JTRF seeks original work predicated on empirical and or theoretical research of } \\
\text { transportation problems and issues. Interest covers air, rail and truck transportation. }\end{array}$ & $\begin{array}{l}\text { www.utexas.edu/depts/ctr } \\
\text { /trf/news/jourja._policy. } \\
\text { html }\end{array}$ \\
\hline Journal of Travel Research & $\begin{array}{l}\text { Published by the Travel and Tourism Research Association (TTRA) the journal seeks } \\
\text { articles on travel research and marketing as defined in the broadest sense. Subjects covered } \\
\text { include security, impact of tourism pricing, measuring customer satisfaction, forecasting, } \\
\text { entertainment, etc. The journal is available electronically to those with a print subscription. }\end{array}$ & $\begin{array}{l}\text { www.sagepub.co.uk/ } \\
\text { journals/details/j0255. } \\
\text { html }\end{array}$ \\
\hline $\begin{array}{l}\text { Knowledge, Technology \& } \\
\text { Policy (KT\&P) } \\
\text { 15/Quarterly }\end{array}$ & $\begin{array}{l}\text { The Editorial Board of KT\&P is receptive to articles resting on the titular tripod. } \\
\text { "Knowledge" means how technologies change the ways we think. Knowledge also refers to } \\
\text { how we organize, access and use information--indeed, how we transform information into } \\
\text { knowledge. "Policy" refers to what we should do about these things (if anything) as } \\
\text { individuals, communities and governments. Articles must be readable by policy-makers and } \\
\text { be mindful of the Board's conviction that objective truth exists and impacts society. } \\
\text { Relatively few articles specifically address aviation. However, the Winter } 2003 \text { edition } \\
\text { reviewed a book on Air Transport. This journal has been in publication since } 1988 \text { (D. } \\
\text { Clark, personal communication, April 6, 2001). }\end{array}$ & www.moted.org/kt\&p \\
\hline $\begin{array}{l}\text { Transport Policy } \\
\text { 10/Quarterly }\end{array}$ & $\begin{array}{l}\text { This journal is intended to bridge the gap between theory and practice in transport. Subject } \\
\text { areas include governmental, not-for-profits and industry policies. The journal views } \\
\text { transport from the broad perspective of including land, sea and air, road and rail, public and } \\
\text { private, motorized and non-motorized, and passenger and freight transport. }\end{array}$ & $\begin{array}{l}\text { //Authors.elsevier.com/ } \\
\text { guideforauthors.html?Pub } \\
\mathrm{ID}=30473 \& \text { dc }=\text { GFA }\end{array}$ \\
\hline $\begin{array}{c}\text { Transport Reviews } \\
\text { 22/Quarterly }\end{array}$ & $\begin{array}{l}\text { Published in London by Taylor \& Francis since } 1981 \text {. An online version is available } \\
\text { starting with the January } 2002 \text { issue. The andience for Transport Reviews is international in } \\
\text { scope and the Joumal's editorial statement indicates that it seeks: "...transnational and } \\
\text { transdisciplinary papers written in a more general, less specialist, style". Examination of the } \\
\text { Spring, } 1990 \text { edition reveals a wide variety of transport articles published, ranging from a } \\
\text { description of the transportation system in Kuwait to one devoted to the planning of } \\
\text { ambulance services in England. In what is an unusual practice, the editors of Transport } \\
\text { Reviews suggest that authors interested in publishing submit an abstract outlining the } \\
\text { proposed research to the editor for their country (in the US-Texas A\&M) before submitting } \\
\text { it for publication. This procedure permits prospective authors to discover the level of the } \\
\text { journal's interest in the subject matter before investing time pursuing traditional publication } \\
\text { methods. This procedure may help avoid long time delays (and perbaps disappointment). }\end{array}$ & $\begin{array}{l}\text { www.tandf.co.uk/journals } \\
\text { /tf/01441647.html }\end{array}$ \\
\hline
\end{tabular}




\begin{tabular}{|c|c|c|}
\hline Transportation & $\begin{array}{l}\text { The continuing purpose of this journal is to promote the free and vigorous exchange of } \\
\text { ideas and experience among the worldwide community actively concerned with } \\
\text { transportation policy, planning and practice. It is published under the umbrella of Kluwer } \\
\text { Academic Publishers and has an international focus. A } 2001 \text { article is entitled "Open skies } \\
\text { and open gates" and reviews airline alliances. }\end{array}$ & $\begin{array}{l}\text { http://ipsapp } 007 . \\
\text { lwwonline.com/ips/ } \\
\text { frames/static.asp? }\end{array}$ \\
\hline $\begin{array}{c}\text { Transportation Joumal } \\
\text { 41/Quarterly }\end{array}$ & $\begin{array}{l}\text { The American Society of Transportation and Logistics, is a professional association of } \\
\text { transportation practitioners and academicians founded in } 1946 \text {. The purposes of the society } \\
\text { "are to establish, promote, and maintain high standards of knowledge and professional } \\
\text { training; formulate a code of ethics for the profession; advance the professional interests of } \\
\text { members of the organization; serve as a source of information and guidance for the fields of } \\
\text { traffic and transportation, logistics, and physical distribution management; and serve the } \\
\text { industry as a whole by fostering professional accomplishments." The Transportation } \\
\text { Journal articles cover such areas as Air Transport, International Transport, Management } \\
\text { Information Systems \& Computer Applications, Regulation/Law, Traffic \& Transport } \\
\text { Management, and Transport Policy. } \\
\text { The Transportation Journal is a good vehicle for aviation researchers to consider for papers } \\
\text { that relate to airline management and/or public policy issues. The Transportation Journal } \\
\text { bas been in publication since } 1962 \text {. }\end{array}$ & www.astl.org/tj.htm \\
\hline $\begin{array}{l}\text { Transportation Law Journal. } \\
\text { 34/Tertiary }\end{array}$ & $\begin{array}{l}\text { The University of Denver Law School, Denver, Colorado, publishes this journal. The } \\
\text { director of the transportation program and former editor of the Journal is Paul Stephen } \\
\text { Dempsey, who is widely recognized in the aviation community. He has long been a } \\
\text { spokesman on many aviation issues and an outspoken critic of the deregulation of the } \\
\text { airline industry. Although the Transportation Law Journal publishes research related to all } \\
\text { modes of transportation, it specializes in aviation, reflecting Dempsey's extensive interest } \\
\text { and background in the field. The Transportation Law Journal has been in existence since } \\
1973 \text {. }\end{array}$ & www.du.edu/tlg/ \\
\hline
\end{tabular}




\begin{tabular}{|c|c|c|}
\hline $\begin{array}{l}\text { Transportation Quarterly } \\
\text { 82/Quarterly } \\
\text { (Publishing ends in 2003) }\end{array}$ & $\begin{array}{l}\text { Unfortunately this historical document ceases publication at the end of } 2003 \text {. (Personal } \\
\text { communication March } 25,2003 \text { ). William Phelps Eno formed a private foundation in his } \\
\text { name in } 1921 \text { to help improve transportation education and research activities. The } \\
\text { Quarterly has sought to publish articles appealing to a wide audience and was an ideal } \\
\text { outlet for applied research that addresses the managerial, engineering, technological, and } \\
\text { policy aspects of aviation (Transportation Quarterly, 1995). Virtually every volume of the } \\
\text { Transportation Quarterly features at least one article on aviation. }\end{array}$ & $\begin{array}{l}\text { www.enotrans.com/ } \\
\text { Publications/ } \\
\text { Transportation_ } \\
\text { Quarterly } \\
\text { /transportation } \\
\text { _quarterly.html }\end{array}$ \\
\hline $\begin{array}{l}\text { Transportation Research } \\
\text { Record: Journal of the } \\
\text { Transportation Research } \\
\text { Board (TRB) } \\
\\
\text { 36/Varies }\end{array}$ & $\begin{array}{l}\text { One of the most important activities of the TRB is the dissemination of current research } \\
\text { results. A primary goal of the publications program is to circulate current information and } \\
\text { research on transportation policy and practice as expeditiously and broadly as possible. The } \\
\text { books, reports, and miscellaneous publications of the Transportation Research Board cover } \\
\text { nine general subject categories: planning, administration, and environment; design; } \\
\text { materials, construction, and maintenance; operations and safety; aviation; public transit; } \\
\text { rail; freight transportation (multimodal); and marine transportation. Encouraging research } \\
\text { and innovation in transportation since 1920 the TRB is a unit of the National Research } \\
\text { Council, a private, nonprofit institution that is the principal operating agency of the } \\
\text { National Academies (http://trb.org). There are several other possible methods for } \\
\text { publishing by the TRB in addition to the Record, which has been published sporadically } \\
\text { since 1963. Instructions for authors are included on the web site. }\end{array}$ & $\begin{array}{l}\text { www4.nas.edu/trb/ } \\
\text { annual.nsf/web/ } \\
\text { information_for_ } \\
\text { authors }\end{array}$ \\
\hline
\end{tabular}


Table 3. Aviation related journals refereed by an editorial board.

\begin{tabular}{|c|c|c|}
\hline $\begin{array}{c}\text { Title } \\
\text { Years Published/ } \\
\text { Publishing Schedule }\end{array}$ & Focus & Web Link \\
\hline $\begin{array}{c}\text { Airport } \\
\text { 14/Bi-monthly }\end{array}$ & $\begin{array}{l}\text { Published by the American Association of Airport Executive. International airport issues } \\
\text { are considered well as those of the United States. Subjects include security, design, } \\
\text { governmental policy, etc. }\end{array}$ & $\begin{array}{l}\text { www.airportnet.org/ } \\
\text { depts/publications/amh } \\
\text { mpg. } \\
\text { htm }\end{array}$ \\
\hline $\begin{array}{l}\text { Airport Press } \\
\text { 25/Monthly }\end{array}$ & $\begin{array}{l}\text { "Airport Press is the monthly airport industry newspaper reporting on national, } \\
\text { international, and local events which impact on air cargo, airport, and passenger segments } \\
\text { of the industry" (Airport Press online, 2/28/03). The magazine publishes "guest editorials } \\
\text { by government and industry leaders." }\end{array}$ & $\begin{array}{l}\text { http://www.airportpress } \\
\text {.com/ }\end{array}$ \\
\hline $\begin{array}{l}\text { Aviation Security } \\
\text { International: The Journal of } \\
\text { Airport \& Airline Security } \\
\text { 8/Bi-monthly }\end{array}$ & $\begin{array}{l}\text { A British online journal that uses an internal editorial review process for articles. The editor } \\
\text { indicates there is consideration of moving to an academic review process. Because of the } \\
\text { timeliness of the subject, it seems desirable to track this possible change. Subjects of } \\
\text { interest include passenger and baggage screening, air rage, etc. (P. Baum, personal } \\
\text { communication, February 21, 2003). }\end{array}$ & www.avsec.com/ \\
\hline $\begin{array}{l}\text { Defense Transportation } \\
\text { Journal (DTJ) } \\
\text { /Bi-monthly }\end{array}$ & 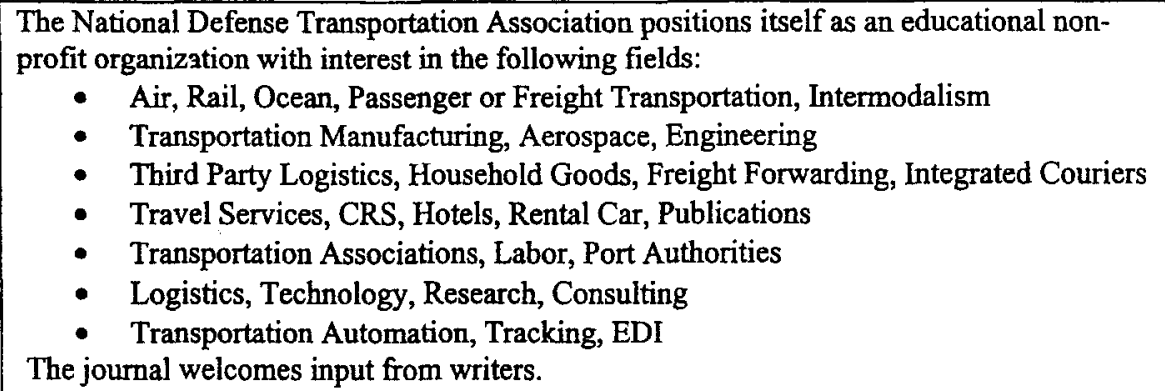 & http://www.ndtahq.com/ \\
\hline
\end{tabular}


Journal of Aviation/Aerospace Education \& Research, Vol. 14, No. 1 [2004], Art. 8 